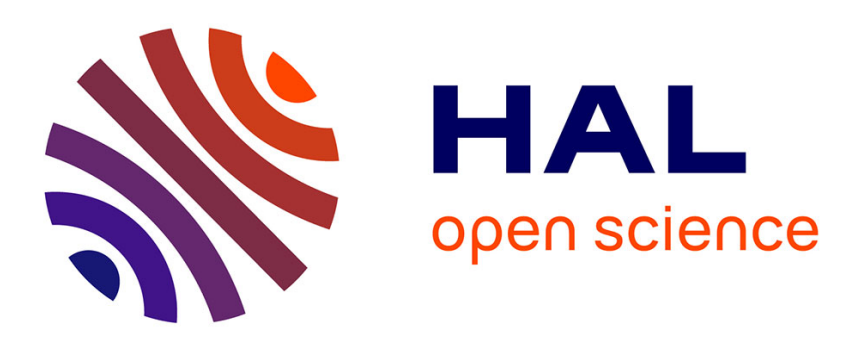

\title{
Resistance to ocean acidification in coral reef taxa is not gained by acclimatization
}

S. Comeau, C. Cornwall, T. Decarlo, S. Doo, C. Carpenter, T. Mcculloch

\section{To cite this version:}

S. Comeau, C. Cornwall, T. Decarlo, S. Doo, C. Carpenter, et al.. Resistance to ocean acidification in coral reef taxa is not gained by acclimatization. Nature Climate Change, 2019, 9 (6), pp.477-483. 10.1038/s41558-019-0486-9 . hal-02178762

\section{HAL Id: hal-02178762 \\ https://hal.sorbonne-universite.fr/hal-02178762}

Submitted on 10 Jul 2019

HAL is a multi-disciplinary open access archive for the deposit and dissemination of scientific research documents, whether they are published or not. The documents may come from teaching and research institutions in France or abroad, or from public or private research centers.
L'archive ouverte pluridisciplinaire HAL, est destinée au dépôt et à la diffusion de documents scientifiques de niveau recherche, publiés ou non, émanant des établissements d'enseignement et de recherche français ou étrangers, des laboratoires publics ou privés. 
1 Resistance to ocean acidification in coral reef taxa is not gained by

2 acclimatization

3

4 Comeau S. ${ }^{1,2,3}$, Cornwall C. E..$^{1,2,4}$, DeCarlo T. M. ${ }^{1,2,5}$, Doo S. S. ${ }^{6}$, Carpenter R.

5 C. ${ }^{6}$, McCulloch M. T. ${ }^{1,2}$

$7{ }^{1}$ The University of Western Australia, Oceans Graduate School, 35 Stirling Highway,

8 Crawley 6009, Western Australia, Australia

$9{ }^{2}$ ARC Centre of Excellence for Coral Reef Studies, 35 Stirling Highway, Crawley

10 6009, Western Australia, Australia

$11{ }^{3}$ Sorbonne Université, CNRS-INSU, Laboratoire d'Océanographie de Villefranche,

12181 chemin du Lazaret, F-06230 Villefranche-sur-mer, France

$13{ }^{4}$ School of Biological Sciences, Victoria University of Wellington, Wellington, New-

14 Zealand.

$15{ }^{5}$ Red Sea Research Center, Division of Biological and Environmental Science and

16 Engineering, King Abdullah University of Science and Technology (KAUST),

17 Thuwal, Saudi Arabia

$18{ }^{6}$ Department of Biology, California State University, 18111 Nordhoff Street,

19 Northridge, CA 91330-8303, USA 


\section{Abstract}

22

23 Ocean acidification (OA) is a major threat to coral reefs, which are built by calcareous

24 species. However, long-term assessments of the impacts of OA are scarce, limiting

25 the understanding of the capacity of corals and coralline algae to acclimatize to high

$26 \mathrm{pCO}_{2}$ levels. Species-specific sensitivities to OA are influenced by its impacts on

27 chemistry within the calcifying fluid (CF). Here, we investigate the capacity of

28 multiple coral and calcifying macroalgal species to acclimatize to elevated $\mathrm{pCO}_{2}$ by

29 determining their chemistry in the CF during a year-long experiment. We found no

30 evidence of acclimatization to elevated $\mathrm{pCO}_{2}$ across any of the tested taxa. The effects

31 of increasing seawater $\mathrm{pCO}_{2}$ on the $\mathrm{CF}$ chemistry were rapid and persisted until the

32 end of the experiment. Our results show that acclimatization of the CF chemistry does

33 not occur within one year, which confirms the threat of OA for future reef accretion

34 and ecological function. 
35 Changes in seawater carbonate chemistry caused by OA generally lead to decreasing

36 calcification of marine organisms ${ }^{1}$ as well as increased dissolution of existing calcium 37 carbonate structures ${ }^{2}$. The magnitude of responses to OA are species-specific and can 38 even be intra-specific in reef taxa, although some species exhibit significant resistance 39 to $\mathrm{OA}^{3-5}$. The physiological mechanisms responsible for declines in calcification in 40 corals and calcifying algae due to OA are, however, still unclear. Short-term 41 experiments on small numbers of species have limited potential to assess whether 42 calcifying organisms can acclimatize to changes in seawater carbonate chemistry, or alternatively, whether species-specific differences in calcification physiology dictates the overall magnitude of responses. Insights into changes in calcification mechanisms can be gained by investigating the response of carbonate chemistry in the calcifying fluid (CF) from which the calcium carbonate is precipitated ${ }^{6}$. Corals exert a strong control on their CF chemistry, with $\mathrm{pH}$ in the $\mathrm{CF}\left(\mathrm{pH}_{\mathrm{cf}}\right)$ maintained above seawater $\mathrm{pH}^{7-9}$. Similarly, the dissolved inorganic carbon (DIC) is concentrated in the CF by $\sim 1.5-2$-fold above seawater DIC ${ }^{10-13}$. As a result, the saturation state within the $\mathrm{CF}$ is $\sim 3-4$ times greater than the surrounding seawater, which, in association with the production of organic matrices, favours the precipitation of calcium carbonate in the CF. While less data on the calcification physiology of tropical calcifying algae are available ${ }^{14}$, the few studies on coralline algae also show that the response of their CF chemistry to seawater carbonate chemistry is similar to that of corals ${ }^{10,15,16}$.

Reduced seawater $\mathrm{pH}$ can decrease $\mathrm{pH}_{\mathrm{cf}}$, though $\mathrm{pH}_{\mathrm{cf}}$ always remains above seawater $\mathrm{pH}^{7}$. However, the magnitude of the effect of seawater $\mathrm{pH}$ on $\mathrm{pH}_{\mathrm{cf}}$ is species-specific ${ }^{7,17}$. In contrast, $\mathrm{DIC}_{\mathrm{cf}}$ increases with temperature and declining seawater $\mathrm{pH}^{17,18}$. Again, the effects on $\mathrm{DIC}_{\mathrm{cf}}$ are also species-specific ${ }^{17}$. The use of laboratory studies to estimate the response of organisms to climate change in situ has been challenged, and this is particularly true for assessments of how climate change could modify carbonate chemistry in the $\mathrm{CF}^{11}$. Massive Porites exhibit, for example, strong seasonal variation in $\mathrm{CF}$ chemistry in situ, where $\mathrm{pH}_{\mathrm{cf}}$ varies by 0.2 units, and $\mathrm{DIC}_{\mathrm{cf}}$ by $20-25 \%$ in one year ${ }^{11,19}$. It was proposed that such effects of seasonal variability in CF chemistry could be masked during laboratory experiments if constant temperature and daily doses of light are employed ${ }^{11}$.

Long-term OA experiments (several months to years) are rare ${ }^{20}$, but they are necessary to rule out short-term responses to treatments, and to determine whether 
acclimatization to such conditions is possible. Outside of laboratory experiments, field observations at naturally acidified sites such as $\mathrm{CO}_{2}$ seeps have been used to provide valuable information on the capacity of organisms to acclimate or adapt (if locally self-recruiting) to $\mathrm{OA}^{21,22}$. The survival and high abundance of massive Porites sp. corals near $\mathrm{CO}_{2}$ seeps has been associated with their capacity to maintain elevated $\mathrm{pH}_{\mathrm{cf}}^{23}$. However, it is difficult to draw conclusions from studies made at $\mathrm{CO}_{2}$ vents alone because those sites experience huge sporadic variations in $\mathrm{pH}$ (up to 1 unit) that are not representative of the future conditions expected on most reefs ${ }^{15,24}$.

The present study was designed to test the year-long effects of OA, in outdoor flumes $^{25}$, on the CF chemistry in the four corals Pocillopora verrucosa, Psammocora profundacella, Acropora pulchra and massive Porites spp. (called Pocillopora, Psammocora, Acropora, and Porites thereafter) and two calcifying algae Lithophyllum kotschyanum and Halimeda minima (Lithophyllum and Halimeda thereafter). We assessed the calcification and CF responses of these organisms exposed to four different $\mathrm{pCO}_{2}$ conditions over one year (2 months for Halimeda). We were able to maintain realistic flow conditions, natural irradiance, and stable $\mathrm{pCO}_{2}$ by using outdoor flumes ${ }^{26}$. Two non-exclusive hypotheses were tested: 1) if acclimatization occurs, corals and calcifying algae would have the capacity to attain conditions of carbonate chemistry in the CF comparable to the control after one year of exposure. This would be the case if carbonate chemistry in the CF is initially affected by OA, but then returns to the level of the control during the one-year experimental period. 2) Seasonal variations in light and temperature would affect the response of the CF chemistry to OA. This would occur if carbonate chemistry in the $\mathrm{CF}$ varies seasonally as a function of light and temperature in a similar manner in all treatments.

\section{Experimental conditions}

Over the year-long incubation, $\mathrm{pCO}_{2}$ treatments remained relatively stable. Overall, the average monthly mean $\mathrm{pCO}_{2}$ values of the treatments were $356 \pm 27$ $\mu \mathrm{atm}, 561 \pm 22 \mu \mathrm{atm}, 714 \pm 34 \mu \mathrm{atm}$, and $1053 \pm 43 \mu \mathrm{atm}$ for the four treatments (mean $\pm \mathrm{SE}, \mathrm{n}=12$ for all). The range of mean seawater temperatures across all four communities was $25.55-29.37^{\circ} \mathrm{C}$, which reflected the seasonal mean at the backreef of Moorea. Mean seawater temperature integrated over the year of incubation did not 
vary greatly between flumes (maximum $0.16^{\circ} \mathrm{C}$ between two flumes). Mean monthly daytime PAR varied seasonally from a minimum in May $\left(219 \pm 8 \mu \mathrm{mol}\right.$ quanta $\mathrm{m}^{-2} \mathrm{~s}^{-}$ $\left.{ }^{1}\right)$ to a maximum in November $\left(478 \pm 77 \mu \mathrm{mol}\right.$ quanta $\left.\mathrm{m}^{-2} \mathrm{~s}^{-1}\right)$. Monthly $\mathrm{A}_{\mathrm{T}}$ mean values across the flumes did not differ (from a minimum of $2286.3 \pm 11.9$ to a maximum of $2294.5 \pm 8.6 \mu \mathrm{mol} \mathrm{kg}{ }^{-1}$ in the 561 and $714 \mu$ atm flumes, respectively) and remained similar to the total alkalinity of the back reef of Moorea.

\section{Calcification and calcifying fluid chemistry}

At the end of the 1-year incubation, calcification of Pocillopora and Porites was not affected by the treatments (Fig. 1), while conversely the calcification of Psammocora and Acropora decreased linearly with $\mathrm{pCO}_{2}$ (slope $\mathrm{p}$-value $=0.022$ and 0.039, respectively, Table S1). Calcification of Lithophyllum also decreased linearly with $\mathrm{pCO}_{2}$ (slope $\mathrm{p}$-value $=0.032$, Table S1).

$\mathrm{pH}_{\mathrm{cf}}$ of the four corals exhibited contrasting responses to the treatment after 1 year. There was no significant linear relationship between $\mathrm{pH}_{\mathrm{cf}}$ or $\mathrm{DIC}_{\mathrm{cf}}$ and $\mathrm{pCO}_{2}$ for Porites, whereas in the three other corals (Psammocora, Pocillopora, and Acropora) there were significant linear relationships between $\mathrm{pH}_{\mathrm{cf}}$ and the $\mathrm{pCO}_{2}$ (slope $\mathrm{p}$-value $<$ 0.01, Table S1, Fig. 2). $\mathrm{DIC}_{\mathrm{cf}}$ responded in the opposite direction of $\mathrm{pH}_{\mathrm{cf}}$, with higher $\mathrm{DIC}_{\mathrm{cf}}$ in the high $\mathrm{pCO}_{2}$ treatments in these three corals (Fig. 3) (slope p-values $=$ 0.008, 0.030, and 0.007; Table S1).

For both algae, $\mathrm{pH}_{\mathrm{cf}}$ decreased linearly with increasing $\mathrm{pCO}_{2}$ (slope $\mathrm{p}$-value $=$ 0.012 and < 0.001; for Lithophyllum and Halimeda, respectively; Table S1, Fig. 2).

There were no consistent linear relationships between the aragonite $\Omega_{\mathrm{cf}}$ and $\mathrm{pCO}_{2}$ in three of the four corals (Pocillopora, Acropora, and Porites, Fig. S1, Table $\mathrm{S} 1)$. However, there was a decrease of $\Omega_{\mathrm{cf}}$ with increasing $\mathrm{pCO}_{2}$ in Psammocora (Table S1, Fig. S1). $\mathrm{Ca}^{2+}{ }_{\mathrm{cf}} / \mathrm{Ca}^{2+}$ Sw was only affected by the $\mathrm{pCO}_{2}$ in Pocillopora (Fig. 4) $\left(\right.$ slope $\mathrm{p}$-value $=0.009$, Table S1) with maximum $\mathrm{Ca}^{2+}{ }_{\mathrm{cf}} / \mathrm{Ca}^{2+}{ }_{\mathrm{Sw}}$ measured in the $1053 \mu \mathrm{atm}$ treatment.

\section{Seasonal variation in calcifying fluid composition}

Seasonal variations in calcifying fluid composition were determined on the two corals Acropora and Porites. These corals were selected because they exhibit 
134 contrasting morphologies and different potential sensitivities to ocean acidification. In

135 Acropora, $\mathrm{pH}_{\mathrm{cf}}$ was consistently higher in the $356 \mu$ atm treatment (Fig. 5), with a

136 significant effect of the treatment (ANOVA, $\mathrm{p}<0.001$ ). There was also a significant

137 effect of treatment (ANOVA, $\mathrm{p}=0.045)$ and time $(\mathrm{p}=0.023)$ on $\Omega_{\mathrm{cf}}$ that was driven

138 by slightly higher $\Omega_{\mathrm{cf}}$ in the lowest $\mathrm{pCO}_{2}$ treatment, particularly at the end of the

139 incubation (Fig. S2). In contrast, DIC $\mathrm{cf}(\mathrm{ANOVA}, \mathrm{p}=0.096)$ and $\mathrm{Ca}^{2+}{ }_{\mathrm{cf}} / \mathrm{Ca}^{2+} \mathrm{Sw}(\mathrm{p}=$

140 0.107) were not affected by the treatment, but were affected by time (both $p<0.001$ )

141 (Fig. 5 and S2). Seawater temperature and the mean daily light did not affect $\mathrm{pH}_{\mathrm{cf}}$ and

$142 \mathrm{DIC}_{\mathrm{cf}}$, while the mean daily light had a positive effect on $\mathrm{Ca}^{2+}{ }_{\mathrm{cf}} / \mathrm{Ca}^{2+}$ sw and $\Omega_{\mathrm{cf}}$

143 (Table S2).

144 For Porites, there was no significant effect of the treatment on $\mathrm{pH}_{\mathrm{cf}}($ ANOVA, $145 \mathrm{p}=0.773), \mathrm{DIC}_{\mathrm{cf}}(\mathrm{p}=0.835), \Omega_{\mathrm{cf}}(\mathrm{p}=0.711)$ and $\mathrm{Ca}^{2+}{ }_{\mathrm{cf}} / \mathrm{Ca}^{2+}$ sw $($ Fig. 5 and S2). There

146 was a seasonal trend with the lowest $\mathrm{pH}_{\mathrm{cf}}$, and the highest $\mathrm{DIC}_{\mathrm{cf}}$, values recorded

147 during the austral winter (Fig 5). This was driven by a negative effect of temperature

148 and light on $\mathrm{pH}_{\mathrm{cf}}$ and positive effect of these parameters on $\mathrm{DIC}_{\mathrm{cf}}$ (Table S3).

\section{Discussion}

During our year-long experiment we found no evidence of acclimatization to

153 elevated $\mathrm{pCO}_{2}$ across four coral and two calcifying algal species. If acclimatization

154 occurred, we would have expected carbonate chemistry in the calcifying fluid to be

155 initially affected by the treatments, then return to levels comparable to that of the

156 controls after one year. Rather, we found that the responses to $\mathrm{pCO}_{2}$ were species-

157 specific, occurred rapidly, and persisted over one year. Three of the four coral species

158 and the two macroalgal species exhibited a decrease in $\mathrm{pH}_{\mathrm{cf}}$, and an increase in $\mathrm{DIC}_{\mathrm{cf}}$

159 for the corals, when seawater $\mathrm{pCO}_{2}$ was increased. This is similar to what has been

160 found previously during shorter term experiments ${ }^{17,18}$. In contrast, the chemistry in the

161 calcifying fluid of Porites did not respond to $\mathrm{pCO}_{2}$. The two species whose

162 calcification was unaffected by OA were from different genera (Pocillopora and

163 Porites), and exhibited different morphologies (branching vs massive). These results

164 confirm the difficulty in predicting species-specific responses to ocean acidification

165 based on functional traits ${ }^{3,27}$. Additionally, the calcifying fluid chemistry of both

166 species exhibited different responses to increased seawater $\mathrm{pCO}_{2}$, with Porites

167 maintaining homeostatic conditions with changing $\mathrm{pCO}_{2}$ and Pocillopora 
compensating a decrease in $\mathrm{pH}_{\mathrm{cf}}$ by increasing $\left[\mathrm{Ca}^{2+}\right]_{\mathrm{cf} .}$. It is these different mechanisms of maintaining favourable CF chemistry that enable constant calcification, observed here and in our previous work ${ }^{10}$ (Fig. 6).

Two lines of evidence demonstrate the lack of acclimatization of the chemistry

172 at the site of calcification to external changes in seawater. First, $\mathrm{pH}_{\mathrm{cf}}$ measured in the

173 corals at the end of the experiment exhibited the commonly described decreases in $174 \mathrm{pH}_{\mathrm{cf}}$ with seawater $\mathrm{pH}$ in three out of four taxa $\mathrm{a}^{7,28}$. The similar relationship between

$175 \mathrm{pH}_{\mathrm{cf}}$ and seawater $\mathrm{pH}$ found in the macroalgae also matched previous results from 176 shorter-term laboratory studies ${ }^{10,15,16}$. Second, the effects of seawater $\mathrm{pCO}_{2}$ on the $\mathrm{CF}$ 177 chemistry were consistent across time and varied in a similar manner in all treatments

178 for Acropora and massive Porites sampled at regular intervals (every 3 and 4 months, 179 respectively). Our results therefore suggest that seawater carbonate chemistry acts 180 relatively quickly to alter CF chemistry and that this effect is maintained after one 181 year. Hence, one year of exposure to the different treatments did not improve or worsen the capacity of five of the six corals and macroalgae investigated to upregulate their proton export ${ }^{29}$ to maintain $\mathrm{pH}_{\mathrm{cf}}$ at ambient levels.

$\mathrm{DIC}_{\mathrm{cf}}$ also displayed a lack of acclimatization. The inverse relationship between $\mathrm{DIC}_{\mathrm{cf}}$ and seawater $\mathrm{pH}$ (and therefore $\mathrm{pH}_{\mathrm{cf}}$ ) found at the end of the experiment has been previously shown both during shorter term experiments lasting only a few weeks or months ${ }^{10}$ and during in situ seasonal observations ${ }^{11,30,31}$. Similar trends were also found in Goniopora sp. exposed for 6 months to variable and constant $\mathrm{pH}^{14}$. Together, this identifies seawater carbonate chemistry as the main driver of this inverse relationship in numerous corals. It also indicates that the ability to increase $\mathrm{DIC}_{\mathrm{cf}}$ as seawater $\mathrm{pH}$ decreases under ocean acidification could be a common feature in many coral genera to limit its negative effects on the precipitation of calcium carbonate.

Chemistry in the $\mathrm{CF}$ of Porites did not respond to seawater $\mathrm{pCO}_{2}$ from the

195 start to the end of the experiment. This result suggests that the capacity of some corals 196 to control $\mathrm{pH}_{\mathrm{cf}}$ and $\mathrm{DIC}_{\mathrm{cf}}$ independently of external seawater conditions (i.e massive 197 Porites) is an inherent characteristic. Observations on Porites cylindrica also showed 198 that this species was able to maintain a constant $\mathrm{pH}_{\mathrm{cf}}$ when exposed to low $\mathrm{pH}$ during 199 a 6-month in situ free ocean $\mathrm{CO}_{2}$ enrichment experiment ${ }^{19}$. The ability of massive 200 Porites to survive under the low $\mathrm{pH}$ conditions at $\mathrm{CO}_{2}$ vents has also been linked with 201 its capacity to maintain elevated $\mathrm{pH}_{\mathrm{cf}}{ }^{23}$. Taken together, the calcification rates and 
$\mathrm{pH}_{\mathrm{cf}}$ of Porites spp. appear to be relatively insensitive to the impacts of OA. However,

203 the response of the Porites genus to OA may be atypical amongst corals. Furthermore,

204 this tolerance may be limited only to particular Porites species, since a pronounced

205 decrease in $\mathrm{pH}_{\mathrm{cf}}$ with seawater $\mathrm{pH}$ was found in P. compressa from Hawaii ${ }^{17}$ and in

206 some massive Porites sp. genotypes ${ }^{32}$.

$207 \mathrm{pH}_{\mathrm{cf}}$ homeostasis ${ }^{24}$ is not the only mechanism of resistance to OA. Here,

208 calcification of Pocillopora was unaffected by the treatments despite a decrease in

$209 \mathrm{pH}_{\mathrm{cf}}$ with seawater $\mathrm{pH}$. Similarly, $\mathrm{pH}_{\mathrm{cf}}$ of Pocillopora damicornis decreased with

210 seawater $\mathrm{pH}$ during a two-month laboratory study but calcification remained

211 constant $^{18}$. The lack of an effect of seawater $\mathrm{pH}$ on the calcification of Pocillopora

212 damicornis was explained by the increase in calcium concentration in the calcifying

213 fluid that enabled the corals to maintain constant precipitation of calcium carbonate

214 despite decreasing $\mathrm{pH}_{\mathrm{cf}}^{33}$. Here, we observed a similar increase in the calcium

215 concentration of Pocillopora verrucosa when seawater $\mathrm{pH}$ decreased, which favoured

216 the maintenance and even the slight (but not statistically significant) increase of $\Omega_{\text {arag }}$

217 cf with $\mathrm{pCO}_{2}$. This result suggests that increasing $\left[\mathrm{Ca}^{2+}\right]$ in response to decreasing $\mathrm{pH}$

218 is a common feature for corals of the genus Pocillopora and could explain the

219 resistance of some Pocilloporidae to OA reported previously ${ }^{34-36}$. The mechanism

220 responsible for increases in $\left[\mathrm{Ca}^{2+}\right]$ still need to be confirmed. However, previous

221 evidence points toward an active transport of calcium by various intracellular

222 pathways to the site of calcification ${ }^{37}$.

223 It has been suggested that short-term laboratory experimental results can be

224 misleading because they do not consider seasonal variations in biotic and abiotic

225 factors. For example, seasonal cycles of $\mathrm{pH}_{\mathrm{cf}}$ and $\mathrm{DIC}_{\mathrm{cf}}$, have been documented on

226 massive Porites sp. from the Great Barrier Reef and Ningaloo Reef, Australia ${ }^{11}$, and

227 Acropora youngei and Pocillopora damicornis from Rottnest Island, Western

228 Australia $^{30}$. Here, the seasonal cycles in Porites $\mathrm{pH}_{\mathrm{cf}}$ and $\mathrm{DIC}_{\mathrm{cf}}$ was conserved across

$229 \mathrm{pH}$ treatments, suggesting that such cycles are not driven by seawater $\mathrm{pH}$ (which were

230 constant across seasons) but rather by other abiotic (light, temperature, nutrient) or

231 biotic parameters (photosynthetic rates, tissue thickness, reproduction cycles, growth

232 rates). Ross et al. ${ }^{30}$ attributed the seasonal variations in $\mathrm{pH}_{\mathrm{cf}}$ and $\mathrm{DIC}_{\mathrm{cf}}$ to temperature.

233 We found similar effects of temperature on $\mathrm{pH}_{\mathrm{cf}}$ and $\mathrm{DIC}_{\mathrm{cf}}$ of Porites. Contrary to

234 conclusions of previous studies ${ }^{11}$, the presence (Porites) and absence (Acropora) of

235 these seasonal trends in $\mathrm{pH}_{\mathrm{cf}}$ and $\mathrm{DIC}_{\mathrm{cf}}$ are related to species-specific effects, rather 
236 than being artefacts arising from a lack of exposure to natural fluctuations of light and

237 temperature that could ultimately alter interpretations of how seawater $\mathrm{pH}$ controls

$238 \mathrm{pH}_{\mathrm{cf}}$. This is supported by the fact that decreases in $\mathrm{pH}_{\mathrm{cf}}$ in response to seawater $\mathrm{pH}$

239 have also occurred in the presence of natural daily $\mathrm{pH}$ and oxygen variability in recent

240 prior work ${ }^{15}$.

241 In conclusion, our study demonstrates that despite the strong capacity of corals

242 and coralline algae to modulate the chemistry at their site of calcification ${ }^{10,15,17}$, the

243 effects of ocean acidification were manifested after one year under realistic

244 experimental conditions in three corals and in the algae. The magnitude of these

245 effects is species-specific, and species' resistance to OA over one year can be linked

246 to two main mechanisms studied here. Corals whose calcification was unaffected by

247 OA either (1) maintained $\mathrm{pH}_{\mathrm{cf}}$ homeostasis (Porites), or (2) increased $\mathrm{Ca}^{2+}{ }_{\mathrm{cf}}$

248 (Pocillopora) (Fig. 6). Increasing DIC $_{\mathrm{cf}}$ under OA is also a compensatory mechanism

249 for decreasing $\mathrm{pH}_{\mathrm{cf}}$, but it was not sufficient here to provide resistance to OA. Our

250 results thus suggest that these mechanisms are likely inherent characteristics, and that

251 some corals and calcifying algae do not have the capacity to acclimate to OA, even

252 over 1-year of experimental treatment. While acclimatization over one year did not

253 occur in our study, further work assessing effects over multiple generations will be

254 necessary to investigate the capacity to acclimate across generations. Finally, the

255 results described here confirm that existing species-specific differences in sensitivities

256 to OA will likely shape the composition of future reefs. 
259 Correspondence and requests for materials should be addressed to Steeve Comeau;

260 comeau@obs-vlfr.fr

\section{Acknowledgments}

262 We thank A.-M. Comeau-Nisumaa, J. D’Olivo, P. Edmunds for support for

263 this study. Funding support was as follows: MTM by an ARC Laureate Fellowship

264 (LF120100049) and ARC Centre of Excellence for Coral Reef Studies

265 (CE140100020), SC by an ARC DECRA (DE160100668), CEC by ARC Centre of

266 Excellence for Coral Reef Studies (CE140100020), and a Rutherford Discovery

267 Fellowship (Royal Society of New Zealand; RDF-VUW1701), RC by a National

268 Science Foundation grant OCE 14- 15268, the Moorea Coral Reef LTER program

269 (NSF OCE 12-36905) and from the Gordon and Betty Moore Foundation. The

270 University of Western Australia's Centre for Microscopy, Characterisation \&

271 Analysis (CMCA). Research was completed under permits issued by the Haut-

272 commissariat de la République en Polynésie Francaise (DRRT) (Protocole d'Accueil

273 2015-2016). This is contribution number 286 of the CSUN Marine Biology Program.

274

275 Author contributions

$276 \mathrm{SC}$ wrote the paper, prepared the experiment, run the geochemical analyses and

277 analysed the data. CC wrote the paper and conducted geochemical analyses. TMD

278 performed geochemical analyses. SD performed the flume experiment. RC and MTM

279 provided vital laboratory facilities. All authors edited the manuscript, contributed

280 intellectual expertise and approved of its submission.

281

282 Data availability

283 All data are available on the public data repositories BCO-DMO (https://www.bco-

284 dmo.org/dataset/756211).

285

286

\section{References}

287

1. Kroeker, K. J. et al. Impacts of ocean acidification on marine organisms: quantifying sensitivities and interaction with warming. Glob. Change Biol. 19, 1884-1896 (2013). 
2. Eyre, B. D. et al. Coral reefs will transition to net dissolving before end of century. Science 359, 908-911 (2018).

3. Comeau, S., Edmunds, P. J., Spindel, N. B. \& Carpenter, R. C. Fast coral reef calcifiers are more sensitive to ocean acidification in short-term laboratory incubations. Limnol. Oceanogr. 59, 1081-1091 (2014).

4. Okazaki, R. R. et al. Species-specific responses to climate change and community composition determine future calcification rates of Florida Keys reefs. Glob. Change Biol. 23, 1023-1035 (2017).

5. Cole, C., Finch, A. A., Hintz, C., Hintz, K. \& Allison, N. Effects of seawater $\mathrm{pCO}_{2}$ and temperature on calcification and productivity in the coral genus Porites spp.: an exploration of potential interaction mechanisms. Coral Reefs 37, 471-481 (2018).

6. Tambutté, S. et al. Coral biomineralization: From the gene to the environment. J. Exp. Mar. Biol. Ecol. 408, 58-78 (2011).

7. McCulloch, M., Falter, J., Trotter, J. \& Montagna, P. Coral resilience to ocean acidification and global warming through $\mathrm{pH}$ up-regulation. Nat. Clim. Change

8. Venn, A. A. et al. Impact of seawater acidification on $\mathrm{pH}$ at the tissue-skeleton 309 interface and calcification in reef corals. Proc. Natl. Acad. Sci. 110, 1634-1639 (2013).

9. Venn, A., Tambutté, E., Holcomb, M., Allemand, D. \& Tambutté, S. Live Tissue Imaging Shows Reef Corals Elevate $\mathrm{pH}$ under Their Calcifying Tissue Relative to Seawater. PLOS ONE 6, e20013 (2011). 
314 10. Comeau, S., Cornwall, C. E., DeCarlo, T. M., Krieger, E. \& McCulloch, M. T.

315 Similar controls on calcification under ocean acidification across unrelated

316 coral reef taxa. Glob. Change Biol. 24, 4857-4868

317 11. McCulloch, M. T., D’Olivo, J. P., Falter, J., Holcomb, M. \& Trotter, J. A. Coral

318 calcification in a changing World and the interactive dynamics of $\mathrm{pH}$ and DIC

319 upregulation. Nat. Commun. 8, 15686 (2017).

320 12. Sevilgen, D. S. et al. Full in vivo characterization of carbonate chemistry at the

321 site of calcification in corals. Sci. Adv. 5, eaau7447 (2019).

322 13. Allison, N. et al. Corals concentrate dissolved inorganic carbon to facilitate $323 \quad$ calcification. Nat. Commun. 5, 5741 (2014).

324 14. Hofmann, L. C., Koch, M. \& Beer, D. de. Biotic Control of Surface pH and 325 Evidence of Light-Induced $\mathrm{H}^{+}$Pumping and $\mathrm{Ca}^{2+}-\mathrm{H}^{+}$Exchange in a Tropical 326 Crustose Coralline Alga. PLOS ONE 11, e0159057 (2016).

327 15. Cornwall, C. E. et al. Resistance of corals and coralline algae to ocean

328 acidification: physiological control of calcification under natural $\mathrm{pH}$ $329 \quad$ variability. Proc R Soc B 285, 20181168 (2018).

330 16. Cornwall, C. E., Comeau, S. \& McCulloch, M. T. Coralline algae elevate pH at the 331 site of calcification under ocean acidification. Glob. Change Biol. 23, 4245$3324256(2017)$.

333 17. Schoepf, V., Jury, C. P., Toonen, R. J. \& McCulloch, M. T. Coral calcification 334 mechanisms facilitate adaptive responses to ocean acidification. Proc $R$ Soc $B$ $335 \quad 284,20172117$ (2017).

336 18. Comeau, S., Cornwall, C. E. \& McCulloch, M. T. Decoupling between the 337 response of coral calcifying fluid $\mathrm{pH}$ and calcification to ocean acidification. $338 \quad$ Sci. Rep. 7, 7573 (2017). 
19. D’Olivo, J. P. \& McCulloch, M. T. Response of coral calcification and calcifying fluid composition to thermally induced bleaching stress. Sci. Rep. 7, 2207 (2017).

20. Tambutté, E. et al. Morphological plasticity of the coral skeleton under $\mathrm{CO}_{2}$ driven seawater acidification. Nat. Commun. 6, 7368 (2015).

21. Barkley, H. C. et al. Changes in coral reef communities across a natural gradient in seawater pH. Sci. Adv. 1, e1500328 (2015).

22. Fabricius, K. E. et al. Losers and winners in coral reefs acclimatized to elevated carbon dioxide concentrations. Nat. Clim. Change 1, 165-169 (2011).

23. Wall, M. et al. Internal pH regulation facilitates in situ long-term acclimation of massive corals to end-of-century carbon dioxide conditions. Sci. Rep. 6, 30688 (2016).

24. Georgiou, L. et al. $\mathrm{pH}$ homeostasis during coral calcification in a free ocean $\mathrm{CO}_{2}$ enrichment (FOCE) experiment, Heron Island reef flat, Great Barrier Reef. Proc. Natl. Acad. Sci. 112, 13219-13224 (2015).

25. Carpenter, R. C., Lantz, C. A., Shaw, E. \& Edmunds, P. J. Responses of coral reef community metabolism in flumes to ocean acidification. Mar. Biol. 165, 66 (2018).

26. Comeau, S., Carpenter, R. C., Lantz, C. A. \& Edmunds, P. J. Ocean acidification accelerates dissolution of experimental coral reef communities. Biogeosciences 12, 365-372 (2015).

27. Barner, A. K. et al. Generality in multispecies responses to ocean acidification revealed through multiple hypothesis testing. Glob. Change Biol. 0, 
363

364

365

366

367

368

369

370

371

28. Holcomb, M. et al. Coral calcifying fluid pH dictates response to ocean acidification. Sci. Rep. 4, 5207 (2014).

29. Ries, J. B. Skeletal mineralogy in a high- $\mathrm{CO}_{2}$ world. J. Exp. Mar. Biol. Ecol. 403, 54-64 (2011).

30. Ross, C. L., Falter, J. L. \& McCulloch, M. T. Active modulation of the calcifying fluid carbonate chemistry $\left(\delta^{11} \mathrm{~B}, \mathrm{~B} / \mathrm{Ca}\right)$ and seasonally invariant coral calcification at sub-tropical limits. Sci. Rep. 7, 13830 (2017).

31. Ross, C. L., Schoepf, V., DeCarlo, T. M. \& McCulloch, M. T. Mechanisms and seasonal drivers of calcification in the temperate coral Turbinaria reniformis at its latitudinal limits. Proc R Soc B 285, 20180215 (2018).

32. Allison, N. et al. The effect of ocean acidification on tropical coral calcification: Insights from calcification fluid DIC chemistry. Chem. Geol. 497, 162-169 (2018).

33. DeCarlo, T. M., Comeau, S., Cornwall, C. E. \& McCulloch, M. T. Coral resistance to ocean acidification linked to increased calcium at the site of calcification. Proc R Soc B 285, 20180564 (2018).

34. Comeau, S. et al. Pacific-wide contrast highlights resistance of reef calcifiers to ocean acidification. Proc. R. Soc. Lond. B Biol. Sci. 281, 20141339 (2014).

35. Putnam, H. M., Mayfield, A. B., Fan, T. Y., Chen, C. S. \& Gates, R. D. The physiological and molecular responses of larvae from the reef-building coral Pocillopora damicornis exposed to near-future increases in temperature and pCO 2. Mar. Biol. 160, 2157-2173 (2013).

36. Kornder, N. A., Riegl, B. M. \& Figueiredo, J. Thresholds and drivers of coral calcification responses to climate change. Glob. Change Biol. (2018). doi:10.1111/gcb.14431 
388 37. Marshall, A. T., Clode, P. L., Russell, R., Prince, K. \& Stern, R. Electron and ion 389 microprobe analysis of calcium distribution and transport in coral tissues. J. $390 \quad$ Exp. Biol. 210, 2453-2463 (2007).

391 
393 Sample collection and preparation

394 This study was carried out in Moorea, French Polynesia, at the Richard B. Gump

395 Research station between November 2015 and November 2016. For this experiment

396 four taxa of coral were used, Psammocora profundacella (Psammocora), Acropora

397 pulchra (Acropora), Pocillopora verrucosa (Pocillopora), and massive Porites spp.

398 (Porites), and two taxa of calcifying macroalgae, the coralline alga Lithophyllum

399 kotschyanum (Lithophyllum) and the green Halimeda minima (Halimeda). Porites,

400 Lithophyllum and Halimeda were part of the back reef communities recreated in the

401 flumes ${ }^{25}$. To increase the number of taxa tested, Psammocora, Acropora, and

402 Pocillopora were maintained in the upstream side of the flumes on separated racks

403 next to the tested communities. These taxa were selected because these taxa are

404 dominant members of the benthic community in the back reef of Moorea ${ }^{38}$. Twenty-

405 four Acropora and Pocillopora were sampled from a common garden at $3 \mathrm{~m}$ depth on

406 the North Shore of Moorea (See ${ }^{39}$ for details). The 5-cm long branches were selected

407 from 6 different colonies for each species. One coral of each colony was used for each

$408 \mathrm{pCO}_{2}$ condition. Twenty-four $\sim 5$-cm in diameter Psammocora were from the back

409 reef where they commonly are found growing on calcareous rubble. Halimeda were

410 hand-picked from the back reef. Porites $(\sim 10-\mathrm{cm}$ diameter, $\mathrm{n}=5$ per treatment $)$ and

411 Lithophyllum ( $\sim 8 \mathrm{~cm}$ in diameter, $\mathrm{n}=4$ per treatment) were chiselled off the back

412 reef of the North Shore of Moorea ${ }^{25}$. Psammocora and Porites were cleaned in the

413 laboratory and the dead skeletons on which they were growing were sawed off, and

414 the exposed skeletons were covered with epoxy-glue. Corals and Lithophyllum were

415 glued to plastic bases with Z-spar epoxy to facilitate handling and labelling of the

416 organisms. Halimeda were placed in black mesh cages positioned at the end of the

417 flumes.

419 Experimental set-up

420 The experimental settings used in this experiment were the same as in a

421 parallel experiment that tested the effects of four $\mathrm{pCO}_{2}$ regimes on back reef

422 communities assembled in $5 \mathrm{~m}$ flumes ${ }^{25,38}$. Complete details of the experimental set-

423 up are provided in Carpenter et al. ${ }^{25}$.

424 Briefly, the organisms were maintained in four $5 \times 0.3 \times 0.3 \mathrm{~m}$ outdoor

425 flumes ${ }^{26}$ for 1 year. After an acclimation period of one week, seawater $\mathrm{pCO}_{2}$ was 
maintained at ambient value in one flume (360 $\mu \mathrm{atm})$ and was ramped up to the other

427 three levels $(\sim 360,560,760$, and $1060 \mu \mathrm{atm})$ over 24 hours. $\mathrm{pCO}_{2}$ was maintained

428 with a negative feedback $\mathrm{pH}$ controller that regulated the bubbling of pure $\mathrm{CO}_{2}$ to

429 maintain seawater $\mathrm{pH}$ at the target $\mathrm{pH}$. $\mathrm{pH}$ varied daily by $\sim 0.1 \mathrm{pH}$ unit to simulate

430 current levels of diurnal variability in the back reef of Moorea ${ }^{25}$. This four $\mathrm{pCO}_{2}$ level

431 design was chosen to detect linear effects of $\mathrm{pCO}_{2}$ on organisms ${ }^{3}$. Using this type of

432 design can circumvent some of the issues around low replication of experimental

$433 \operatorname{tanks}^{40}$. Discrete measurements of $\mathrm{pH}_{\mathrm{T}}$ and total alkalinity were made to check the

434 carbonate chemistry in the flumes. $\mathrm{pH}_{\mathrm{T}}$ was measured directly in the flume using a

435 handheld $\mathrm{pH}$ meter that was mounted with a DG 115-SC electrode (Mettler Toledo,

436 Columbus, OH, USA) calibrated with a TRIS buffer. Total alkalinity was measured

437 using an open-cell titrator (T50, Mettler Toledo) and accuracy was checked using

438 certified seawater.

439 Seawater was circulated in the flumes at $0.1 \mathrm{~m} \mathrm{~s}^{-1}$ to match the average yearly

440 seawater velocity in the back reef of Moorea ${ }^{41}$. Freshly pumped sand filtered seawater

441 (corresponding to a mesh size of $500 \mu \mathrm{m}$ ) was continuously delivered to the flumes at

$442 \sim 5 \mathrm{~L} \mathrm{~min}^{-1}$ to maintain constant $\mathrm{A}_{\mathrm{T}}$ and dissolved oxygen levels within the flumes.

443 The corals were not fed but small particles (i.e. $<500 \mu \mathrm{m})$ were not filtered and

444 served as potential food source. Light levels were adjusted with shade cloths to match

445 maximum intensities typically ranging between 1000 and $2000 \mu \mathrm{mol}$ quanta $\mathrm{m}^{-2} \mathrm{~s}^{-1}$ in

446 the back reef of Moorea. Because the flumes were exposed to natural sunlight, light

447 varied strongly seasonally and daily. Temperature was controlled to approximate the

448 mean monthly seawater temperature in the back reef of Moorea, which ranged from

$44929.3^{\circ} \mathrm{C}$ in April to $25.8^{\circ} \mathrm{C}$ in September ${ }^{38}$.

450

\section{Calcification}

453 chemistry. Net calcification of the organisms was determined using the buoyant

454 weight technique ${ }^{42}$. The difference in buoyant weight between the beginning and end

455 of the one year-long incubation was converted to dry weight of aragonite for the

456 corals and calcite for the Lithophyllum to calculate net calcification. Calcification

457 rates were normalized to surface area $\left(\mathrm{mg} \mathrm{cm}^{-2}\right)$ determined using the aluminium foil

458 or the wax dipping method at the end of the incubation. Organisms that exhibited

459 clear signs of damage (e.g. broken branches) that could have affected their weight 
were excluded from the calcification analysis (4 Psammocora, 2 Pocillopora, and 1 Acropora).

$p H_{c f}$ and $D I C_{c f}$

Skeletons were stained by placing the organisms for 48 hours in seawater enriched with the fluorescent dye calcein at $50 \mathrm{mg} \mathrm{L}^{-1}$ with a $\mathrm{pH}$ adjusted to $\sim 8.1$ by the addition of $\mathrm{NaOH}$ prior to the start of the experiment. The stain line was used to identify the part of the skeleton that grew during the experiment (Fig. S3). The $\delta^{11} \mathrm{~B}$ proxy method was used to estimate $\mathrm{pH}$ in the calcifying fluid of all taxa $\left(\mathrm{pH}_{\mathrm{cf}}\right)^{7}$ and the $\delta^{11} \mathrm{~B}$ and $\mathrm{B} / \mathrm{Ca}$ method was used to estimate the dissolved inorganic carbon concentration in the calcifying fluid (DIC $\mathrm{Cf}_{\mathrm{c}}$ ) in the aragonitic taxa ${ }^{11,43}$. Measurements of geochemistry were conducted on the dead skeleton after the experimental period. Skeleton was sampled from the tip of the branches or the top 1-2 $\mathrm{mm}$ of the skeleton for the 6 Pocillopora and Psammocora individuals, and 3 Lithophyllum per treatment. This portion of the skeleton was selected to sample material deposited during the last months of the experiment to detect any potential acclimatization to the experimental conditions. Because Halimeda degraded in the flumes, they were replaced several times during the experiment. The sampling for geochemistry was conducted on 3 Halimeda per treatment that were in the flumes for $\sim 2$ months. Only the top segments were used to ensure that they developed under the experimental conditions. Because the branches of Acropora extend linearly and quickly (i.e., $5-10 \mathrm{~cm} \mathrm{y}^{-1}$ ) it was possible to sample from four individuals per treatment skeleton parts that corresponded to different time points of the year of incubation (Fig. S3). The first section corresponded to the start of the experiment (i.e. the stain line). The rest of the

48412 months linear extension was divided in four and was assumed to represent the 485 growth after 0-3, 3-6, 6-9, and 9-12 months in the different treatments. Likewise, for 486 three Porites individuals per treatment, four portions of the skeleton were sampled.

487 One sample of the skeleton was taken below the stain line to represent the conditions 488 prior to the experiment and the skeleton grown above the stain line was divided in 489 three equal parts that were assumed to roughly represent the growth during the period $490 \quad 0-4,4-8$, and 8-12 months. Seasonal changes in temperature were confirmed using 491 the inverse relationship between $\mathrm{Sr} / \mathrm{Ca}$ and temperature for Porites. The sections 492 prior to the start of the experiment and the one just below the tissue (section month 8493 12) had the highest $\mathrm{Sr} / \mathrm{Ca}$ corresponding to the coldest temperature recorded during 
the austral winter to early spring (July to October). The lowest $\mathrm{Sr} / \mathrm{Ca}$ were recorded for the period 0-4 and 4-8 months confirming that in these sections of the skeleton corresponded to the months November to February and March to June, respectively, when temperature where the highest in the flumes (see Table $\mathrm{S} 1 \mathrm{in}^{38}$ ). The $\mathrm{Sr} / \mathrm{Ca}$ proxy temperature reconstructions were not successful with Acropora, probably because of its perforate skeleton.

The entire selected portions of the skeleton were crushed to powder in a mortar and pestle. Therefore, all measurements represent an integration of the average conditions in the calcifying fluid (over two months) when the selected portions of the skeleton were formed. The measurements integrate the diel effects of light and $\mathrm{pH}$ that varied similarly across treatments. All powders were processed subsequently in the clean laboratory of the Advanced Geochemical Facility for Indian Ocean Research (AGFIOR, University of Western Australia (UWA) for dissolution and dilution to 10-ppm Ca solutions. Ten mg of each sample was placed in $6.25 \% \mathrm{NaClO}$ for 15 mins, rinsed in Milli-Q water then dried for $24 \mathrm{~h}$. Samples were then dissolved in $0.51 \mathrm{~N} \mathrm{HNO}_{3}$, and the $\delta^{11} \mathrm{~B}$ was quantitatively separated on ion exchange columns. $\delta^{11} \mathrm{~B}$ was measured on a multicollector inductively coupled plasma mass spectrometry

511 (NU II). Measurements of the international carbonate standard JCP-1 yielded a mean 512 value of $24.42 \pm 0.05 \%$ o (mean $\pm \mathrm{SE}, \mathrm{n}=12)$, which is similar to the $24.33 \pm 0.11 \%$ o 513 reported previously ${ }^{44}$. Calculations of $\mathrm{pH}_{\mathrm{cf}}$ based on $\delta^{11} \mathrm{~B}$ were made in $\mathrm{R}$ using the 514 calculations of ${ }^{45}$ :

$$
\mathrm{pH}_{\mathrm{cf}}=\mathrm{pK}_{\mathrm{B}}-\log \left[\frac{\left(\delta^{11} \mathrm{~B}_{\mathrm{SW}}-\delta^{11} \mathrm{~B}_{\mathrm{carb}}\right)}{\left(\alpha_{(\mathrm{B} 3-\mathrm{B} 4)} \delta^{11} \mathrm{~B}_{\mathrm{carb}}-\delta^{11} \mathrm{~B}_{\mathrm{SW}}+1000\left(\alpha_{(\mathrm{B} 3-\mathrm{B} 4)}-1\right)\right)}\right]
$$

where $\mathrm{pK}_{\mathrm{B}}$ is the dissociation constant dependent on temperature and salinity,

$517 \delta^{11} \mathrm{~B}_{\mathrm{sw}}=39.61$, and $\alpha_{\mathrm{B} 3-\mathrm{B} 4}$ is the boron isotopic fractionation factor for the $\mathrm{pH}$

518 dependent equilibrium of the borate $\left(\mathrm{B}(\mathrm{OH})_{4}{ }^{-}\right)$relative to the boric acid $\left(\mathrm{B}(\mathrm{OH})_{3}\right)$

519 species in the calcifying fluid, with a value of $1.0272^{46}$. Temperature and salinity

520 were representative of the average conditions in the flumes at which the selected

521 portions of the skeleton were grown.

$\mathrm{B} / \mathrm{Ca}$ ratios, measured on the same material, and $\delta^{11} \mathrm{~B}$, were utilized to determine $\left[\mathrm{CO}_{3}{ }^{2-}\right]$ and $[\mathrm{DIC}]$ at the site of calcification $[\mathrm{DIC}]_{\mathrm{cf}}$ following ${ }^{11}$ for corals.

$524 \mathrm{~B} / \mathrm{Ca}$ ratios were determined on the same aliquot of the solution used for $\mathrm{pH}_{\mathrm{cf}}$

525 estimates, and $\mathrm{DIC}_{\mathrm{cf}}$ was calculated from estimates of carbonate ion concentrations

526 using the following equations described in McCulloch et al. ${ }^{11}$ : 


$$
\left[\mathrm{CO}_{3}^{2-}\right]_{\mathrm{cf}}=\mathrm{K}_{\mathrm{D}}\left[\mathrm{B}(\mathrm{OH})_{4}^{-}\right]_{\mathrm{cf}} /(\mathrm{B} / \mathrm{Ca})_{\mathrm{CaCO}_{3}}
$$

$$
\text { Where } K_{\mathrm{D}}=K_{\mathrm{D} .0} \exp \left(-k_{K D}\left[\mathrm{H}^{+}\right]_{\mathrm{T}}\right) \text { with } K_{\mathrm{D}, 0}=2.97 \pm 0.17 \times 10^{-3}( \pm 95 \% \mathrm{CI}), k_{K_{\mathrm{D}}}
$$

$529=0.0202 \pm 0.042$. The concentration of $\mathrm{DIC}_{\mathrm{cf}}$ was then calculated from estimates of

$530 \mathrm{pH}_{\mathrm{cf}}$ and $\left[\mathrm{CO}_{3}{ }^{2-}\right]_{\mathrm{cf}}$. It was not possible to determine correct $\mathrm{DIC}_{\mathrm{cf}}$ values for Halimeda

531 likely because of dissolution and precipitation of calcium carbonate between the day

532 and the night. $\mathrm{DIC}_{\mathrm{cf}}$ was not determined on Lithophyllum because their skeleton is

533 made of high $\mathrm{Mg}$ Calcite for which no inorganic precipitation experiment linking

$534 \mathrm{~B} / \mathrm{Ca}$ and $\left[\mathrm{CO}_{3}{ }^{2-}\right]_{\mathrm{cf}}$ have been made.

\section{Raman spectroscopy}

537 Confocal Raman spectroscopy was used to determine for the corals estimates 538 of calcifying fluid aragonite saturation state $\Omega_{\text {arag cf }}{ }^{47}$. Measurements were conducted 539 on a WITec Alpha300RA+ using a $785 \mathrm{~nm}$ infrared laser, a 20x objective with 0.5 540 numerical aperture, and a $1200 \mathrm{~mm}^{-1}$ grating to achieve a spectral resolution of 541 approximately $1.3 \mathrm{~cm}^{-1}$. Skeleton powders were placed on glass slides and topography 542 maps were made with the TrueSurface module. The automated stage followed the 543 topography while conducting Raman measurements so that the optics were always in 544 focus on the sample surfaces. 100 spectra were collected per sample in a $300 \mu \mathrm{m}$ by $545300 \mu \mathrm{m}$ grid using $1 \mathrm{~s}$ integrations. Spectra with poor signal $(<50$ intensity units) or 546 contaminated by cosmic rays were excluded.

547 The widths of the $v_{1}$ peaks were used as proxy measures of $\Omega_{\text {arag of }}{ }^{47} \cdot \mathrm{CaCO}_{3}$

548 minerals precipitating from more supersaturated solutions incorporate more impurities 549 and are more disordered, which causes Raman peak broadening due to greater 550 distributions of C-O bond lengths ${ }^{47}$. We used the abiogenic aragonite calibration 551 equation of ${ }^{47}$ to calculate $\Omega_{\text {arag cf }}$ for the coral species from the $v_{1}$ full width at half 552 maximum intensity (FWHM). The mean and median of the standard errors for each 553 individual $\Omega_{\text {arag cf }}(\mathrm{n}=193)$ were 0.19 and 0.16 units, respectively, where these 554 uncertainties are based on the 100 replicate spectra collected for each individual. 555 Repeated measurement of JCp-1 were used for instrument drift correction based on its $556 \Omega_{\text {arag cf }}$ of 12.3 (DeCarlo et al., 2017). The largest of these $\Omega_{\text {arag cf }}$ corrections, which 557 were applied systematically to all samples measured in different analytical sessions, 558 was 2 units. Analyses of Porites, Psammocora, and Pocillopora were all conducted 559 within single analytical sessions, and therefore comparisons among treatments are not 
sensitive to JCp-1 drift corrections. Acropora samples were analysed in two sessions,

561 however, the $\Omega_{\text {arag of }}$ means of the corrected Acropora data were indistinguishable

562 between the two (10.65 \pm 0.14 and $10.59 \pm 0.08$, standard errors $)$, making it unlikely

563 that the JCp-1 corrections led to any artificial differences.

564

$565\left[\mathrm{Ca}^{2+}\right]_{c f}$ determination

$566 \quad\left[\mathrm{Ca}^{2+}\right]_{\mathrm{cf}}$ of corals was calculated as:

$567 \quad\left[\mathrm{Ca}^{2+}\right]_{\mathrm{cf}}=\Omega_{\mathrm{Ar}} * K_{\mathrm{sp}} /\left[\mathrm{CO}_{3}^{2-}\right]_{\mathrm{cf}}$

568 where $\left[\mathrm{CO}_{3}^{2-}\right]_{\mathrm{cf}}$ and $\Omega_{\text {arag } c f}$ are derived from boron systematics and Raman

569 spectroscopy, respectively ${ }^{47} \cdot \mathrm{Ca}_{\mathrm{cf}}^{2+} / \mathrm{Ca}_{\mathrm{sw}}^{2+}$ ratios were calculated by normalizing to

$570\left[\mathrm{Ca}^{2+}\right]_{\mathrm{sw}}$, which was estimated from seawater salinity (average $\left.=35.5\right)$. Estimates of

$571\left[\mathrm{Ca}^{2+}\right]_{\mathrm{sw}}$ were made based on the assumptions that metabolic activity (calcification)

572 did not change the relationship seawater salinity $\left[\mathrm{Ca}^{2+}\right]_{\mathrm{sw}}$. This assumption was

573 supported by the fact that seawater was pumped from Cook's Bay where there is no

574 reef and only very few corals.

Statistical analyses

The assumptions of normality and equality of variance were evaluated through

578 graphical analyses of residuals using the R software. Because the experiment was

579 designed to detect linear effects of $\mathrm{pCO}_{2}$ on the tested organisms, linear relationships

580 between the dependant variables at the end of the experiment (calcification, $\mathrm{pH}_{\mathrm{cf}}$,

$581 \mathrm{DIC}_{\mathrm{cf}}, \Omega_{\text {arag cf, }}$ and $\left.\mathrm{Ca}^{2+}{ }_{\mathrm{cf}}\right)$ and the explanatory variable $\left(\mathrm{pCO}_{2}\right)$ were investigated. To

582 test for the effects of time on $\mathrm{pH}_{\mathrm{cf}}, \mathrm{DIC}_{\mathrm{cf}}, \Omega_{\mathrm{arag}}$ cf, and $\mathrm{Ca}^{2+}{ }_{\mathrm{cf}}$ of Acropora and Porites,

583 repeated measured ANOVAs were used with individual coral as a random factor and

584 the treatment and time as fixed effects. The effects of light, temperature and $\mathrm{pCO}_{2}$ on

$585 \mathrm{pH}_{\mathrm{cf}}, \mathrm{DIC}_{\mathrm{cf}}, \Omega_{\mathrm{arag}}$, and $\mathrm{Ca}^{2+}{ }_{\mathrm{cf}}$ of Acropora and Porites were tested using multiple

586 linear regressions. All statistical analyses were done with $\mathrm{R}$ and the package nlme was

587 used for the repeated measured ANOVAs. 


\section{References (Methods section)}

38. Edmunds, P. J., Doo, S. S. \& Carpenter, R. C. Changes in coral reef community structure in response to year-long incubations under contrasting $\mathrm{pCO}_{2}$ regimes. (In review).

39. Shaw, E. C., Carpenter, R. C., Lantz, C. A. \& Edmunds, P. J. Intraspecific variability in the response to ocean warming and acidification in the scleractinian coral Acropora pulchra. Mar. Biol. 163, 210 (2016).

40. Cornwall, C. E. \& Hurd, C. L. Experimental design in ocean acidification research: problems and solutions. ICES J. Mar. Sci. 73, 572-581 (2016).

41. Hench. Episodic circulation and exchange in a wave-driven coral reef and lagoon system. Limnol. Oceanogr. 53, 2681-2694 (2008).

42. Davies, P. S. Short-term growth measurements of corals using an accurate buoyant weighing technique. Mar. Biol. 101, 389-395 (1989).

43. Holcomb, M., DeCarlo, T. M., Gaetani, G. A. \& McCulloch, M. Factors affecting B/Ca ratios in synthetic aragonite. Chem. Geol. 437, 67-76 (2016).

44. Foster, G. L. et al. Interlaboratory comparison of boron isotope analyses of boric acid, seawater and marine $\mathrm{CaCO}_{3}$ by MC-ICPMS and NTIMS. Chem. Geol. 358, 1-14 (2013).

45. Trotter, J. et al. Quantifying the $\mathrm{pH}$ 'vital effect' in the temperate zooxanthellate coral Cladocora caespitosa: Validation of the boron seawater pH proxy. Earth Planet. Sci. Lett. 303, 163-173 (2011).

46. Klochko, K., Kaufman, A. J., Yao, W., Byrne, R. H. \& Tossell, J. A. Experimental measurement of boron isotope fractionation in seawater. Earth Planet. Sci. Lett. 248, 276-285 (2006). 
614 47. DeCarlo, T. M. et al. Coral calcifying fluid aragonite saturation states derived 615 from Raman spectroscopy. Biogeosciences 14, 5253-5269 (2017).

616 


\section{Legends}

Fig. 1. Effects of four $\mathrm{pCO}_{2}$ treatments $(\sim 360,550,700$ and $1050 \mu \mathrm{atm})$ on the surface area-normalized net calcification rates. Calcification over the 1-year long experiment was measured on the corals Psammocora profundacella (A), Pocillopora verrucosa (B), Acropora pulchra (C), massive Porites sp. (D), and the coralline alga Lithophyllum kotschyanum (E). Individual rates are shown as dots and the squares represent the mean $\pm \mathrm{SE}(\mathrm{n}=5$ for Psammocora; $\mathrm{n}=6$ or 5 for Pocillopora and Acropora; $\mathrm{n}=5$ for Porites and $\mathrm{n}=4$ for Lithophyllum). Linear regressions and the $95 \%$ confidence intervals are shown when the regressions had a statistically significant slope $(\mathrm{p}<0.05)$.

Fig. 2. Estimates of $\mathrm{pH}$ in the calcifying fluid $\left(\mathrm{pH}_{\mathrm{cf}}\right)$ at the end of the 1-year experiment. The geochemical proxy $\delta^{11} \mathrm{~B}$ was used to estimate $\mathrm{pH}_{\mathrm{cf}}$ of the corals Psammocora profundacella (A), Pocillopora verrucosa (B), Acropora pulchra (C), and massive Porites sp. (D) and the algae Lithophyllum kotschyanum (E) and Halimeda minima $(\mathrm{F})$. Individual rates are shown as dots and the squares represent the mean \pm SE ( $\mathrm{n}=6$ or 5 for Psammocora and Pocillopora; $\mathrm{n}=4$ for Acropora; $\mathrm{n}=3$ for Porites and Halimeda, and $\mathrm{n}=4$ for Lithophyllum). Linear regressions and the $95 \%$ confidence intervals are shown when the regressions had a statistically significant slope $(\mathrm{p}<0.05)$.

Fig. 3. Estimates of dissolved inorganic carbon in the calcifying fluid ( $\left.\mathrm{DIC}_{\mathrm{cf}}\right)$ at the end of the 1-year incubation period. The geochemical proxy $\delta^{11} \mathrm{~B}$ and $\mathrm{B} / \mathrm{Ca}$ were used to estimate $\mathrm{DIC}_{\mathrm{cf}}$ of the corals Psammocora profundacella (A), Pocillopora verrucosa (B), Acropora pulchra (C), and massive Porites sp.(D). Individual rates are shown as dots and the squares represent the mean \pm SE ( $\mathrm{n}=6$ or 5 for Psammocora and Pocillopora; $\mathrm{n}=4$ for Acropora; $\mathrm{n}=3$ for Porites). Linear regressions and the $95 \%$ confidence intervals are shown when the regressions had a statistically significant slope $(\mathrm{p}<0.05)$.

Fig 4. Ratio between the calcium in the calcifying fluid $\left(\mathrm{Ca}^{2+}{ }_{\mathrm{cf}}\right)$ and the calcium in seawater $\left(\mathrm{Ca}^{2+} \mathrm{Sw}\right)$ in the four studied corals. $\mathrm{Ca}^{2+}{ }_{\mathrm{cf}}$ was calculated from estimates of aragonite saturation state and $\mathrm{DIC}_{\mathrm{cf}}$. Individual rates are shown as dots and the squares represent the mean $\pm \mathrm{SE}(\mathrm{n}=6$ or 5 for Psammocora and Pocillopora; $\mathrm{n}=4$ for Acropora; $\mathrm{n}=3$ for Porites). Linear regressions and the $95 \%$ confidence intervals are shown when the regressions had a statistically significant slope $(\mathrm{p}<0.05)$.

Fig. 5. Temporal variations of $A$. pulchra and massive Porites sp. calcifying fluid $\mathrm{pH}$ and DIC. The skeleton of $A$. pulchra was sampled to select sections grown at the start of the experiment, and after $\sim 0-3,3-6,6-9$ and 9-12 months of experiment (panels A and B), while the skeleton of massive Porites sp. was sampled to select sections corresponding to the start of the experiment, and after $\sim 0-4,4-8,8-12$ months of experiment (panels $\mathrm{C}$ and D). Month 0 corresponds to November 2015. Error bars show SE.

Fig. 6. Schematic summary of the responses to ocean acidification measured in the corals Acropora pulchra, Psammocora profundacella, massive Porites sp., and Pocillopora verruca. The calcifying fluid chemistry of the two corals whose calcification was affected by OA exhibited a decrease in $\mathrm{pH}_{\mathrm{cf}}$ and an increase in 
$667 \mathrm{DIC}_{\mathrm{cf}}$, while $\mathrm{Ca}^{2+}$ cf was constant. In contrast, in the corals with calcification 668 unaffected by OA two different responses were found in Porites and Pocillopora. 
Psammocora

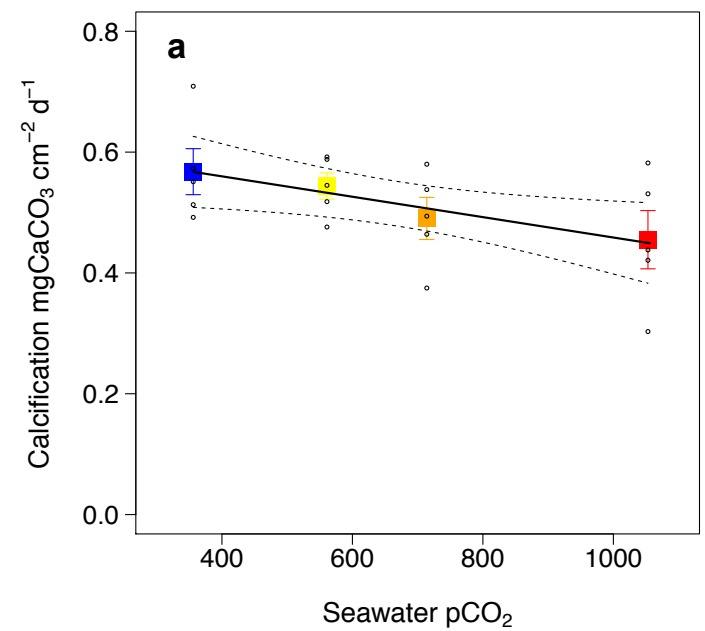

\section{Porites}

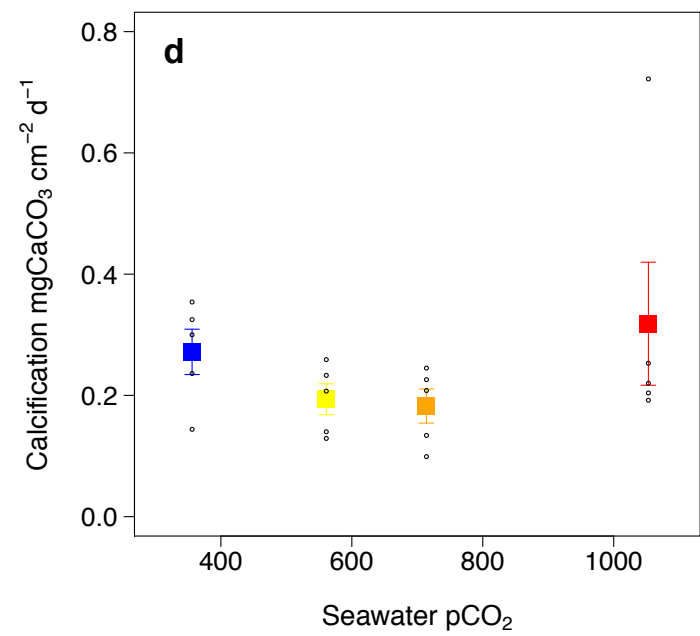

Pocillopora

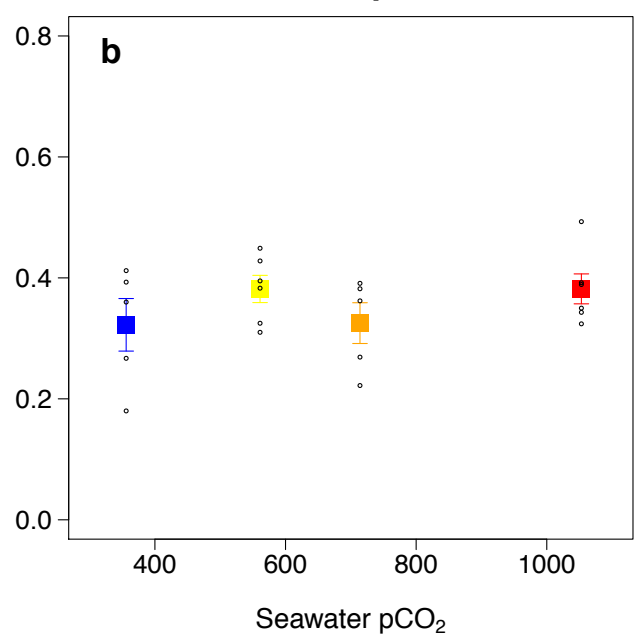

Lithophyllum

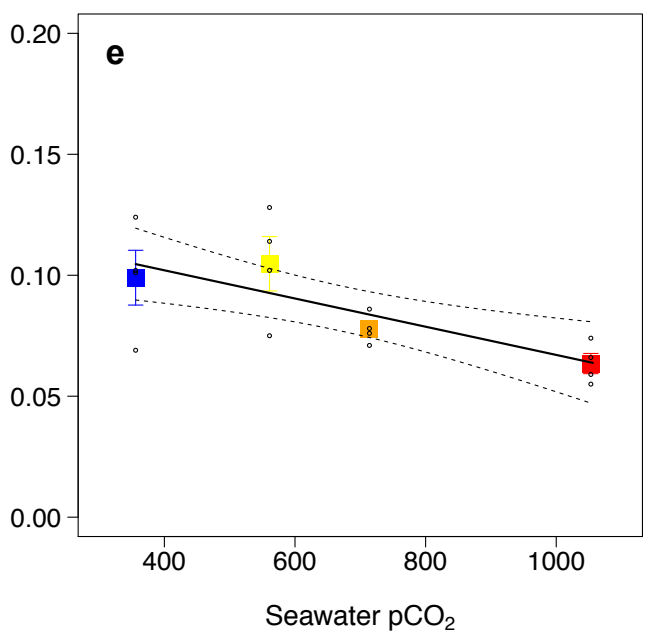

Acropora

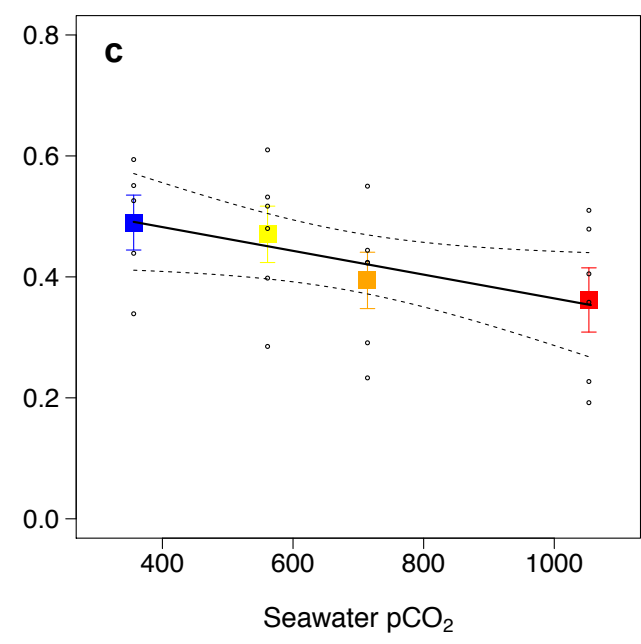




\section{Pocillopora}

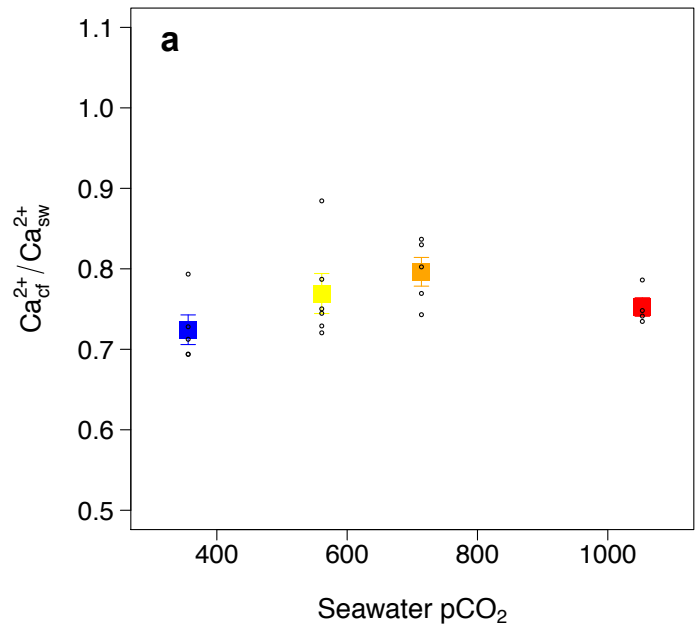

Acropora

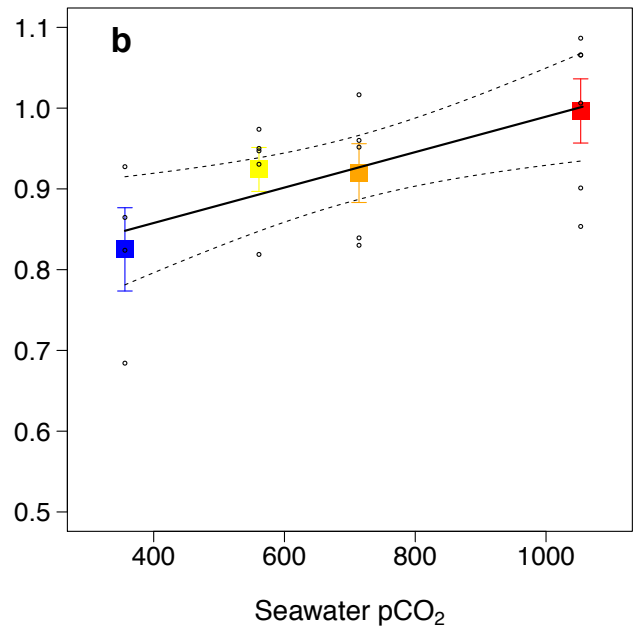

Porites
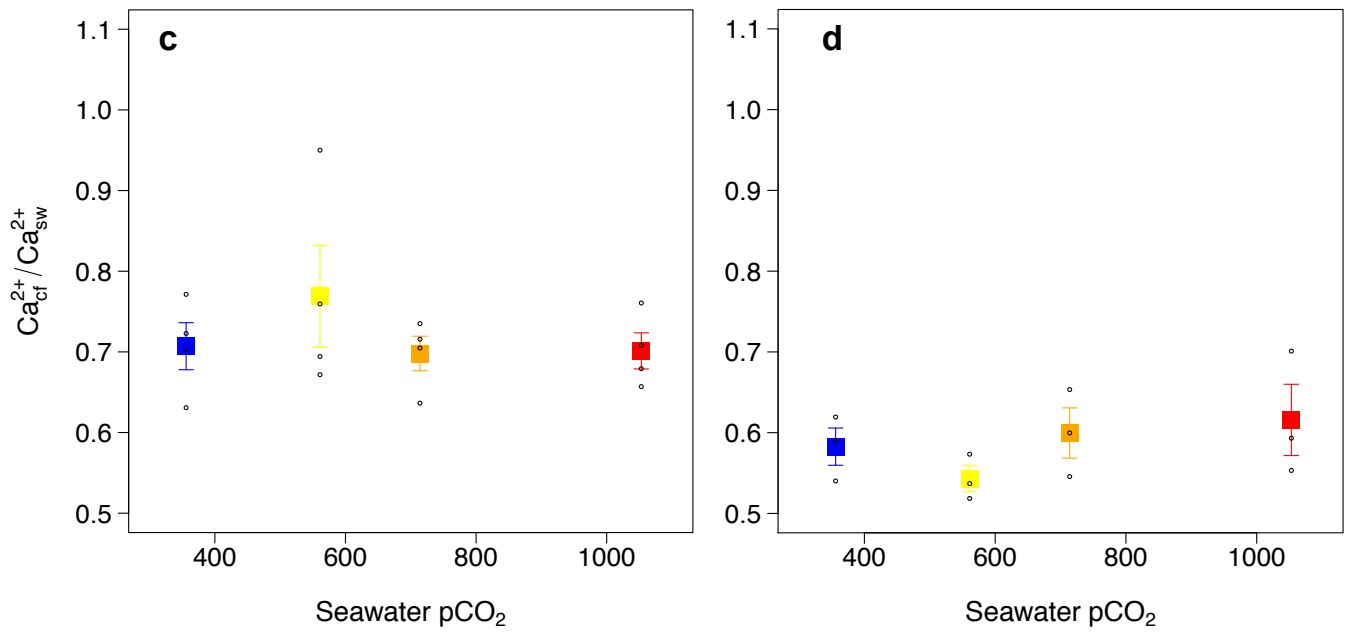


\section{Species-specific response of calcification to OA}

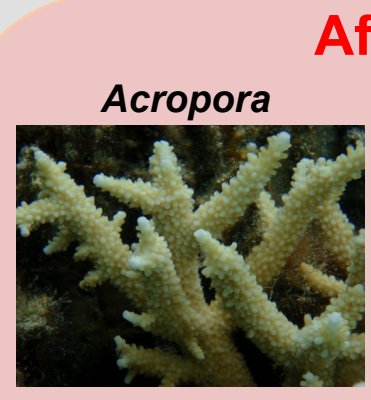

Affected

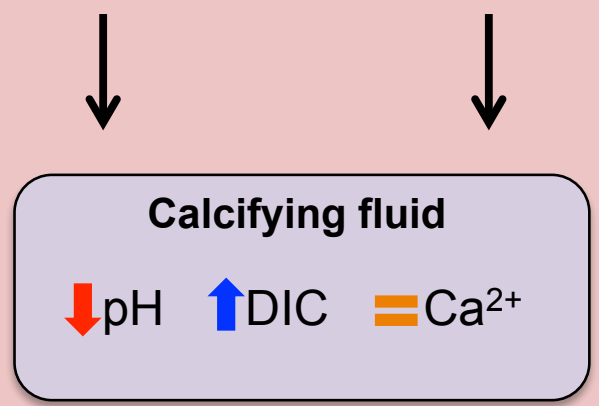

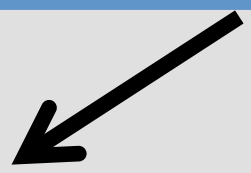

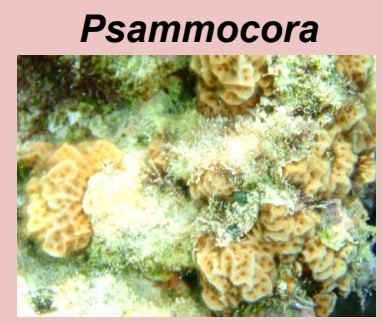

Porites

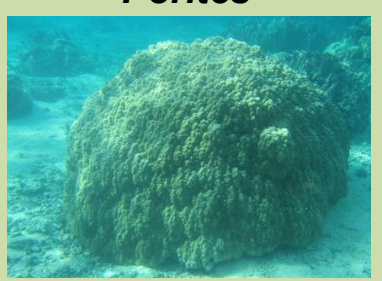

$\downarrow$

Homeostasis $\downarrow$

Calcifying fluid $\mathrm{EH}$

$=\mathrm{DIC}=\mathrm{Ca}^{2+}$
Not affected

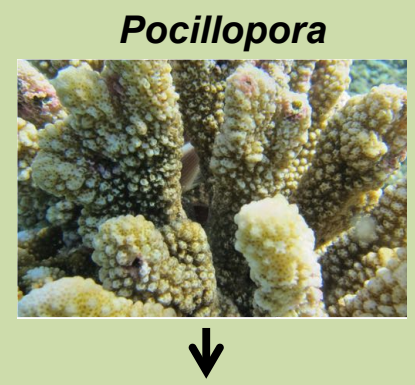

$\mathrm{Ca}^{2+}{ }_{\text {cf }}$ increase $\downarrow$

Calcifying fluid $\mathrm{pH}$ TDIC $\mathrm{Ca}^{2+}$ 
Fig. S1. Estimates of the aragonite saturation state in the calcifying fluid ( $\Omega_{\text {arag cf }}$ ) of corals at the end of the 1-year incubation. Confocal Raman spectroscopy was used to estimate $\Omega_{\text {arag cf }}$ of the corals Psammocora profundacella (A), Pocillopora verrucosa (B), Acropora pulchra (C), and massive Porites sp. (D). Individual rates are shown as dots and the squares represent the mean \pm SE ( $\mathrm{n}=6$ or 5 for Psammocora and

Pocillopora; $\mathrm{n}=4$ for Acropora; $\mathrm{n}=3$ for Porites). Linear regressions and the $95 \%$ confidence intervals are shown when the regressions had a statistically significant slope $(\mathrm{p}<0.05)$.
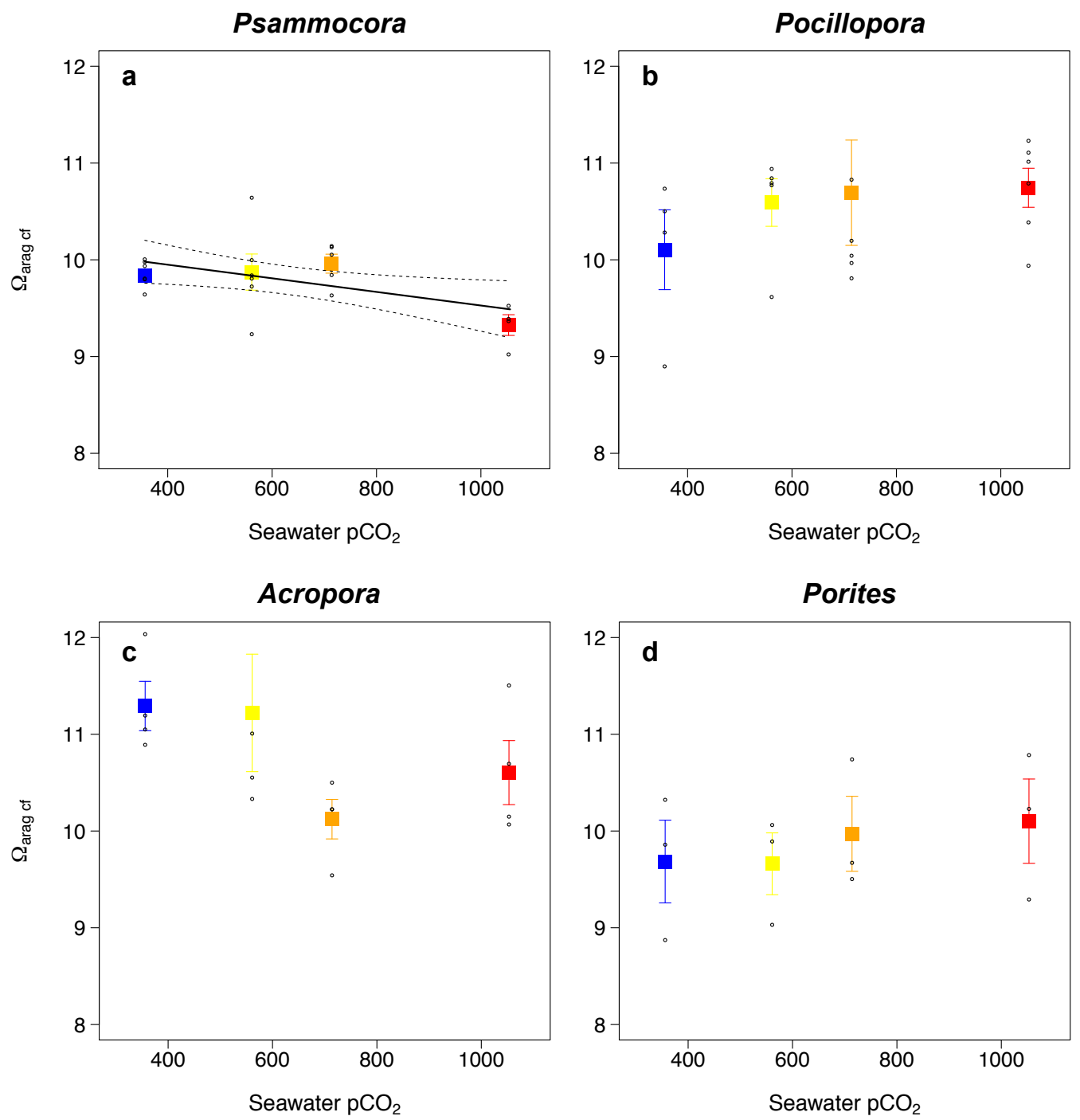
Fig S2. Temporal variations of $A$. pulchra and massive Porites sp. calcifying fluid $\Omega$

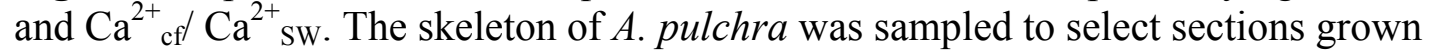
at the start of the experiment, and after $\sim 0-3,3-6,6-9$ and 9-12 months of experiment (panels A and B), while the skeleton of massive Porites sp. was sampled to select sections corresponding to the start of the experiment, and after $\sim 0-4,4-8,8-12$ months of experiment (panels C and D). Month 0 corresponds to November 2015. Error bars show SE.
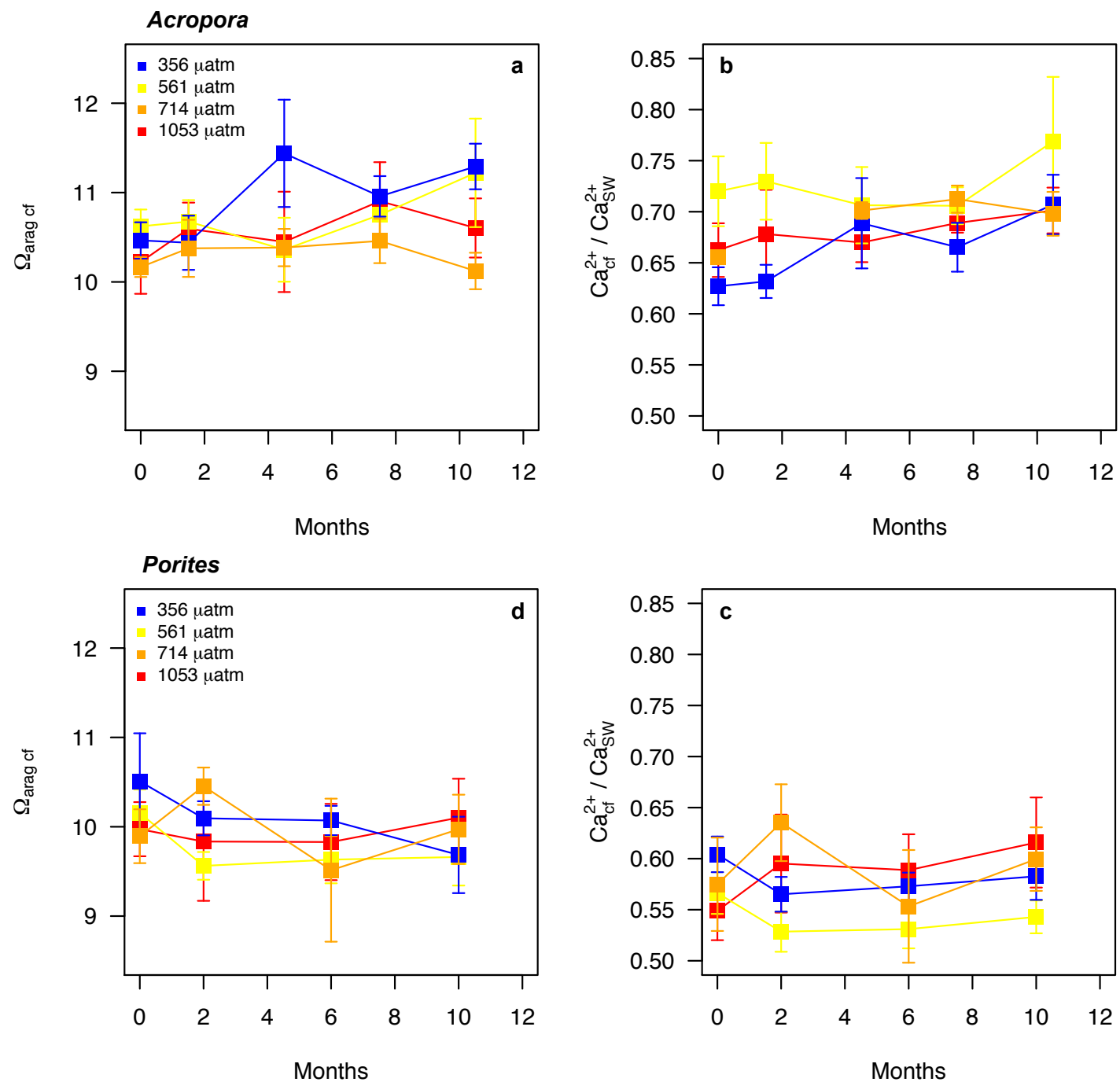
Fig. S3. Schematic showing the portions of the skeleton of Acropora pulchra that were selected to represent the conditions in the calcifying fluid at the start of the experiment (section 0), and after $\sim 0-3$ (section 1), 3-6 (section2), 6-9 (section 3), and 9-12 (section 4) months of experiment. The green lines represent the portions of the skeleton that were selected for each growth period.

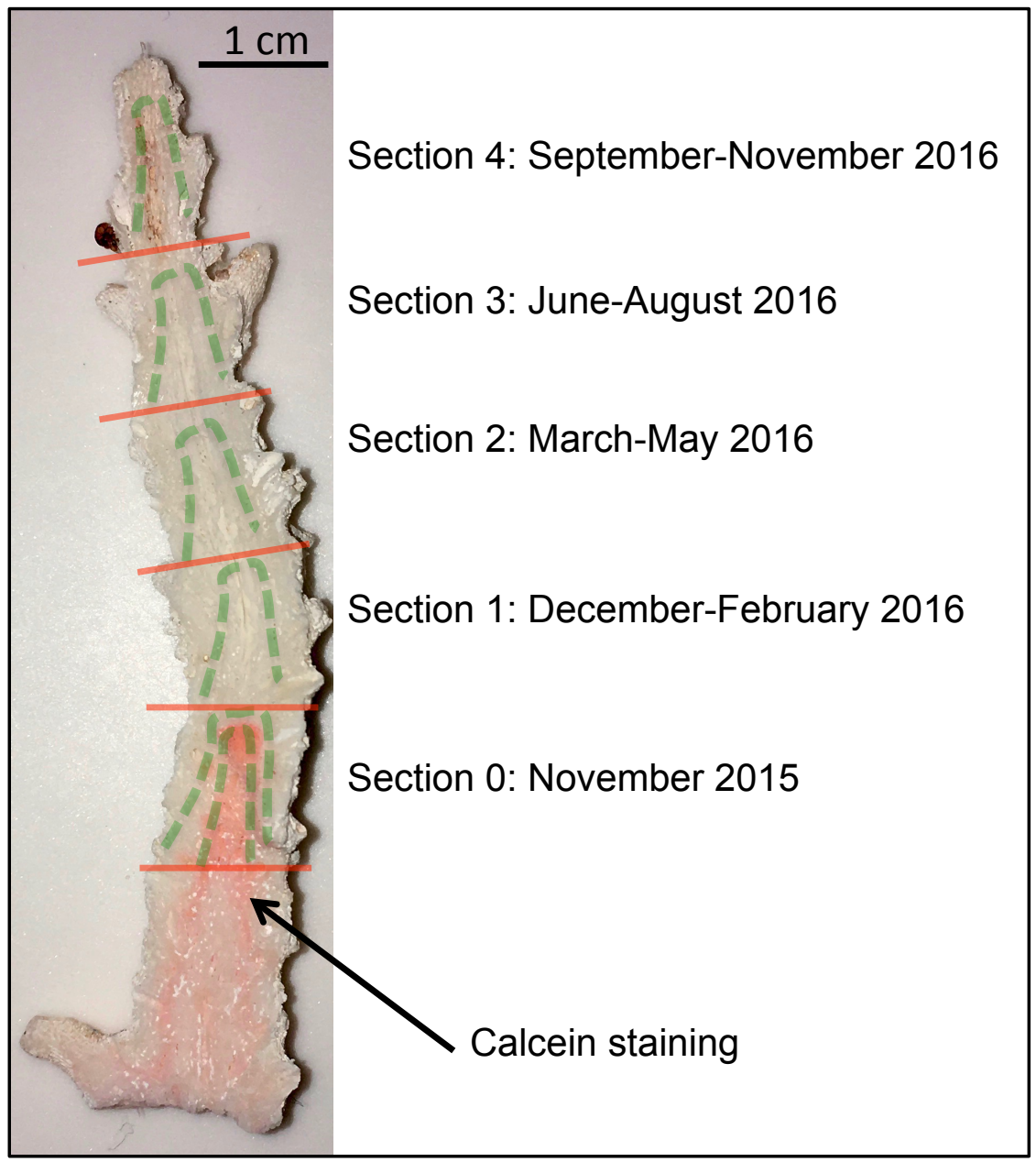


Table S1: Parameters of the linear estimates of the relationship between calcification, $\mathrm{pH}_{\mathrm{cf}}$, DICcf, Ca2+cf, and $\Omega_{\mathrm{cf}}$, and seawater $\mathrm{pCO}_{2}$ ( $\left.\mu \mathrm{atm}\right)$.

\begin{tabular}{llllll} 
Species & Parameter & Equation & $\begin{array}{c}\text { Slope } \\
\text { p-value }\end{array}$ & dF & F \\
\hline Psammocora & $\mathrm{Calcification}$ & $0.63-1.6810^{-4} * \mathrm{pCO}_{2}$ & $\mathbf{0 . 0 2 5}$ & 18 & 5.958 \\
& $\mathrm{pH}_{\mathrm{cf}}$ & $8.61-1.4910^{-4} * \mathrm{pCO}_{2}$ & $<\mathbf{0 . 0 0 1}$ & 20 & 20.68 \\
& $\mathrm{DIC}_{\mathrm{cf}}$ & $2818+0.35 * \mathrm{pCO}_{2}$ & $\mathbf{0 . 0 1 8 3}$ & 18 & 6.738 \\
& $\mathrm{Ca}^{2+}{ }_{\mathrm{cf}}$ & $0.73+1.1010^{-5} * \mathrm{pCO}_{2}$ & 0.39 & 18 & 0.775 \\
& $\Omega_{\mathrm{cf}}$ & $10.23-7.010^{-4} * \mathrm{pCO}_{2}$ & $\mathbf{0 . 0 2 5}$ & 19 & 5.95 \\
\hline Pocillopora & $\mathrm{Calcification}$ & $0.31+6.1210^{-5} * \mathrm{pCO}_{2}$ & 0.326 & 20 & 1.015 \\
& $\mathrm{pH}_{\mathrm{cf}}$ & $8.56-1.7910^{-4} * \mathrm{pCO}_{2}$ & $<\mathbf{0 . 0 0 1}$ & 22 & 16.81 \\
& $\mathrm{DIC}_{\mathrm{cf}}$ & $2849+0.30 * \mathrm{pCO}_{2}$ & $\mathbf{0 . 0 3 5 9}$ & 21 & 5.026 \\
& $\mathrm{Ca}^{2+}{ }_{\mathrm{cf}}$ & $0.77+2.1910^{-4} * \mathrm{pCO}_{2}$ & $\mathbf{0 . 0 0 7}$ & 19 & 8.934 \\
& $\Omega_{\mathrm{cf}}$ & $10.03+7.6310^{-4} * \mathrm{pCO}_{2}$ & 0.316 & 19 & 1.061 \\
\hline Acropora & $\mathrm{Calcification}$ & $0.56-1.9710^{-4} * \mathrm{pCO}_{2}$ & $\mathbf{0 . 0 4 6 5}$ & 21 & 4.475 \\
& $\mathrm{pH}_{\mathrm{cf}}$ & $8.54-1.2710^{-4} * \mathrm{pCO}_{2}$ & $\mathbf{0 . 0 1 6}$ & 14 & 7.518 \\
& $\mathrm{DIC}_{\mathrm{cf}}$ & $3551+0.62 * \mathrm{pCO}_{2}$ & $\mathbf{0 . 0 0 5}$ & 14 & 11.18 \\
& $\mathrm{Ca}^{2+}{ }_{\mathrm{cf}}$ & $0.74-3.6310^{-5} * \mathrm{pCO}_{2}$ & 0.636 & 14 & 0.234 \\
& $\Omega_{\mathrm{cf}}$ & $11.6-1.210^{-3} * \mathrm{pCO}_{2}$ & 0.162 & 14 & 2.18 \\
\hline Porites & $\mathrm{Calcification}$ & $0.18+8.6810^{-5} * \mathrm{pCO}_{2}$ & 0.466 & 18 & 0.5558 \\
& $\mathrm{pH}_{\mathrm{cf}}$ & $8.55-4.8410^{-5} * \mathrm{pCO}_{2}$ & 0.281 & 10 & 1.299 \\
& $\mathrm{DIC}_{\mathrm{cf}}$ & $3874+0.15 * \mathrm{pCO}_{2}$ & 0.519 & 10 & 0.447 \\
& $\mathrm{Ca}^{2+}{ }_{\mathrm{cf}}$ & $0.54+6.810^{-5} * \mathrm{pCO}_{2}$ & 0.276 & 10 & 1.33 \\
& $\Omega_{\mathrm{cf}}$ & $9.40+6.710^{-4} * \mathrm{pCO}_{2}$ & 0.36 & 10 & 0.921 \\
\hline Hithophyllum & $\mathrm{Calcification}$ & $0.12-5.8310^{-5} * \mathrm{pCO}_{2}$ & $\mathbf{0 . 0 0 4}$ & 14 & 11.64 \\
& $\mathrm{pH}_{\mathrm{cf}}$ & $8.77-9.0510^{-5} * \mathrm{pCO}_{2}$ & $\mathbf{0 . 0 1 8}$ & 12 & 7.489 \\
\hline Halimeda & $\mathrm{pH}_{\mathrm{cf}}$ & $8.51-1.4010^{-4} * \mathrm{pCO}_{2}$ & $<\mathbf{0 . 0 0 1}$ & 7 & 51.12
\end{tabular}


Table S2: Parameters of the multiple linear estimates of the relationship between, $\mathrm{pH}_{\mathrm{cf}}, \mathrm{DICcf}, \mathrm{Ca}^{2+}{ }_{\mathrm{cf}}$, and $\Omega_{\mathrm{cf}}$, and seawater mean temperature, mean daily light, and $\mathrm{pCO}_{2}$ treatment in Acropora.

\begin{tabular}{lllll} 
Parameter & $\begin{array}{l}\text { Explanatory } \\
\text { variable }\end{array}$ & Estimate & $\begin{array}{l}\text { Standard } \\
\text { error }\end{array}$ & P-value \\
\hline $\mathrm{pH}_{\mathrm{cf}}$ & Temperature & -0.0109 & 0.0006 & 0.058 \\
& Light & -0.0001 & 0.0001 & 0.151 \\
& $\mathrm{pCO}_{2}$ & 0.0268 & 0.0004 & $<\mathbf{0 . 0 0 1}$ \\
$\mathrm{DIC}_{\mathrm{cf}}$ & Temperature & 7.680 & 35.163 & 0.828 \\
& Light & 0.607 & 0.559 & 0.280 \\
& $\mathrm{pCO}_{2}$ & 111.37 & 25.353 & $<\mathbf{0 . 0 0 1}$ \\
$\Omega_{\mathrm{cf}}$ & Temperature & -0.028 & 0.092 & 0.760 \\
& Light & 0.003 & 0.001 & $\mathbf{0 . 0 3 7}$ \\
$\mathrm{Ca}^{2+}{ }_{\mathrm{cf}}$ & $\mathrm{pCO}_{2}$ & -0.143 & 0.065 & $\mathbf{0 . 0 3 2}$ \\
& Temperature & -0.0073 & 0.0079 & 0.354 \\
& Light & -0.0004 & 0.0001 & $\mathbf{0 . 0 0 2}$ \\
& $\mathrm{pCO}_{2}$ & 0.0013 & 0.0056 & 0.817
\end{tabular}


Table S3: Parameters of the multiple linear estimates of the relationship between, $\mathrm{pH}_{\mathrm{cf}}, \mathrm{DICcf}, \mathrm{Ca}^{2+}{ }_{\mathrm{cf}}$, and $\Omega_{\mathrm{cf}}$, and seawater mean temperature, mean daily light, and $\mathrm{pCO}_{2}$ treatment in Porites.

\begin{tabular}{lllll} 
Parameter & $\begin{array}{l}\text { Explanatory } \\
\text { variable }\end{array}$ & Estimate & $\begin{array}{l}\text { Standard } \\
\text { error }\end{array}$ & P-value \\
\hline $\mathrm{pH}_{\mathrm{cf}}$ & Temperature & -0.0278 & 0.0096 & $\mathbf{0 . 0 0 6}$ \\
& Light & -0.0006 & 0.0002 & $\mathbf{0 . 0 0 4}$ \\
& $\mathrm{pCO}_{2}$ & -0.0103 & 0.0065 & 0.120 \\
$\mathrm{DIC}_{\mathrm{cf}}$ & Temperature & 143.41 & 47.96 & $\mathbf{0 . 0 0 5}$ \\
& Light & 2.62 & 0.99 & $\mathbf{0 . 0 1 1}$ \\
& $\mathrm{pCO}_{2}$ & 21.16 & 32.74 & 0.99 \\
$\Omega_{\mathrm{cf}}$ & Temperature & 0.027 & 0.118 & 0.820 \\
& Light & -0.002 & 0.002 & 0.390 \\
$\mathrm{Ca}^{2+}{ }_{\mathrm{cf}}$ & $\mathrm{pCO}_{2}$ & -0.024 & 0.080 & 0.766 \\
& Temperature & -0.0058 & 0.0102 & 0.575 \\
& Light & 0.00002 & 0.0002 & 0.942 \\
& $\mathrm{pCO}_{2}$ & 0.0068 & 0.0069 & 0.335
\end{tabular}

